\title{
Pengaruh Pelatihan dan Penerapan Teknologi Tepat Guna (TTG) Terhadap Keberdayaan Pengrajin Batik Tulis Ramah Lingkungan
}

\author{
Mardiana Andarwati ${ }^{(1)}$, Edi Subiyantoro ${ }^{(2)}$, Tutut Subadyo ${ }^{(3)}$ \\ ${ }^{1}$ Fakultas Teknologi Informasi, Universitas Merdeka Malang \\ ${ }^{2}$ Fakultas Ekonomi Bisnis, Universitas Merdeka Malang \\ ${ }^{3}$ Fakultas Teknik Arsitektur, Universitas Merdeka Malang \\ Email: ${ }^{1}$ mardiana.andarwati@ unmer.ac.id, ${ }^{2}$ edi_subiyantoro@yahoo.co.id, \\ 3 tutut.subadyo@unmer.ac.id
}

\section{Tersedia Online di \\ http://www.jurnal.unublitar.ac.id/ index.php/briliant}

\section{Sejarah Artikel}

Diterima pada 7 Juni 2018

Disetuji pada 24 Juni 2018

Dipublikasikan pada 13 Agustus 2018 Hal. 280-286

\section{Kata Kunci:}

pelatihan, teknologi tepat guna, pemberdayaan, pengrajin batik tulis

\section{DOI:}

http://dx.doi.org/10.28926/briliant .v3i3.189

\begin{abstract}
Abstrak: Kurangnya pelatihan dan tidak ada teknologi tepat guna yang berdampak pada pemberdayaan pengrajin batik. Masalahnya adalah bagaimana pengaruh pelatihan dan teknologi tepat guna bagi pemberdayaan pengrajin batik?. Desain penelitian menggunakan penelitian survei dengan sampel dan kuesioner sebagai sarana pengumpulan data. Manajer dan pengrajin batik yang melaksanakan pelatihan dan penerapan teknologi tepat guna adalah 32 orang sebagai sampel sehingga penelitian ini merupakan penelitian sensus. Hasil dari penelitian ini adalah pelatihan dan teknologi yang tepat untuk mempengaruhi pemberdayaan perajin batik melalui kegiatan kelompok batik dan dilatih melalui program pemberdayaan batik dan penerapan teknologi tepat guna sehingga dapat meningkatkan kuantitas produksi dan kualitas produk.
\end{abstract}

Sentra batik Trenggalek mempunyai potensi sebagai unggulan daerah. Motif klasik khas batik yang dikenal dengan ciri khas batik cengkeh mulai berkembang melalui pembuatan proses batik tulis dengan teknik pewarna alami dan sementara itu pengrajin batik mulai langka karena proses pembuatannya membutuhkan ketelatenan maka diperlukan penerapan teknologi tepat guna salah satunya meja batik ramah lingkungan untuk digunakan sebagai replika motif batik pada kain mori agar pengrajin batik dapat meningkatkan produktivitas.

Keberdayaan pengrajin batik tulis dengan berkonsep ramah lingkungan adalah pembuatan proses batik tulis dengan pewarna alami serta dengan media meja gambar berbahan kayu dengan memberikan pelatihan serta penggunaan alat yang berteknologi tepat guna agar pengrajin batik lebih mudah menerapkannya. Pelatihan bagi pemilik sekaligus sebagai pengelola Usaha Mikro Kecil Menengah (UMKM) agar bisa menjadi lebih efektif dan berdampak pada perkembangan usaha yang lebih berkualitas khususnya di UMKM Batik Tulis.

Menurut Saaty dan Niemira (2006), peningkatan keberdayaan yaitu pelatihan peningkatan produksi, pemasaran, sumber daya manusia, dan teknologi tepat guna. Menurut Chan (2015), pelatihan adalah salah satu sarana mengurangi penurunan kualitas sumber daya manusia dan organisasi untuk menghadapi inovasi teknologi yang berkembang. Sedangkan menurut Situmorang dan Safri 
(2011), penggunaan teknologi tepat guna merupakan alat untuk mensejahterakan masyarakat dengan memprioritaskan kelompok yang akan ditingkatkan kemampuannya melalui pemanfaatan teknologi tepat guna untuk meningkatkan kualitas kerja usaha melalui pendampingan agar teknologi tepat guna menjadi lebih optimal. Menurut Andarwati dan Jatmika (2017), penerimaan teknologi dari UKM akan mempengaruhi sikap dari pengguna saat menggunakan teknologi tersebut. Sehingga sikap tersebut bisa menunjang keberdayaan para pengrajin batik. UMKM batik tulis di Trenggalek berkonsep pada ramah lingkungan artinya proses produksi dengan menggunakan pewarna alami dan alat yang digunakan untuk proses pengerjaan batik tulis berbahan kayu yaitu meja gambar batik untuk mempermudah kegiatan replika motif batik pada kain mori agar lebih cepat dan lebih berkualitas.

UMKM batik tulis di Trenggalek berkonsep pada ramah lingkungan artinya proses produksi dengan menggunakan pewarna alami dan alat yang digunakan untuk proses pengerjaan batik tulis berbahan kayu yaitu meja gambar batik untuk mempermudah kegiatan replika motif batik pada kain mori agar lebih cepat dan lebih berkualitas.

Berdasarkan uraian di atas maka terciptanya keberdayaan bagi UMKM Batik Tulis perlu dilakukan pelatihan produksi, pelatihan pemasaran, pelatihan sumber daya manusia dan teknologi tepat guna agar menuju peningkatan kualitas sumber daya manusia dan kualitas kerja yang disertai dengan pendampingan penggunaan teknologi tepat guna.

Permasalahan UMKM batik tulis Trenggalek adalah dari segi produksi (menerapkan SOP batik tulis, melakukan pembuatan motif batik berbasis IT), pemasaran (menerapkan promosi dengan memanfaatkan market place, penerapan web site, $p$-catalog, dan e-catalog), sumber daya manusia (dilaksanakan pelatihan oleh instruktur, dilakukan pendampingan dan pembinaan tentang pencatatan keuangan dan perencanaan produksi) dan teknologi (membuat desain dan menerapkan desain meja gambar batik tulis).

Keberdayaan merupakan unsur yang mendasar untuk mengembangkan diri demi mencapai tujuan yang diinginkam melalui kemampuan individu. Menurut Sutanto, Sudantoko, dan Maktub (2012) bahwa keberdayaan adalah memiliki daya, dan daya artinya kekuatan, sedangkan berdaya artinya mempunyai kekuatan. Menurut Iswanaji dan Bondan (2015), bahwa indikator keberdayaan adalah untuk tujuan menunjukkan seseorang berdaya atau tidak adalah kemampuan ekonomi, kemampuan untuk mengakses manfaat kesejahteraan, kemampuan kulktur, dan politis. Indikator keberdayaan dari aspek ekonomi dan aspek non ekonomi. Menurut Susilowati, Mujahirin, Waridin, Tri, Agung (2005) dan Sukirno (2010), bahwa aspek ekonomi dengan indikator keberdasikulayaan adalah akses dari informasi pasar, akses dari usaha, dan akses dari teknologi. Aspek non ekonomi adalah akses untuk menembus batas, akses melobi, dan adanya peran dari stakeholder.

Menurut Dessler (2006) dan Sikula (1981), pelatihan adalah pemberian ketrampilan sesuai kebutuhan yang berkaitan dengan pekerjaan melalui proses pendidikan jangka pendek dengan tahapan yang sistematis. Menurut Sutrisno (2009), pelatihan diberikan terkait dengan ketrampilan dan kemampuan yang dibutuhkan dan menurut Soeprihanto (2001) dengan adanya pelatihan akan memperbaiki kemampuan karyawan melalui peningkatan ketrampilan operasional 
dalam menjalankan pekerjaan. Menurut Mangkunegara (2013), indikator pelatihan adalah adanya tujuan dari penelitian, jenis-jenis pelatihan, materi yang diberikan, penggunaan metode, kualifikasi dari peserta yang dilatih, dan waktu yang disediakan untuk pelatihan.

Menurut Muhi (2009), teknologi tepat guna dalam praktek menerapkan konsep manajemen modern dengan tujuan upaya optimalisasi hasil poduksi atau pendapatan. Penerapan menuju optimalisasi hasil produksi atau pendapatan industri batik perlu penggunaan teknologi yang sesuai dengan sasaran yaitu teknologi yang inovatif berupa alat dan metode/teknik/cara beserta pendampingan disaat penggunaan, dibuatkan HaKI agar teknologi yang didesain, dibuat, dan diterapkan memiliki hak paten dan terlindungi, pelatihan penerapan teknologi baru yang tepat guna. Menurut Muhi (2009), indikator teknologi tepat guna adalah adanya suatu konversi sumber daya alam, tenaga kerja yang diserap, industri rumah tangga menjadi terpicu, dan pendapatan masyarakat yang semakin meningkat.

Penelitian terdahulu yang dilakukan oleh Widyasanti, Putri, dan Dwiratna (2016) menggunakan metode participatory approach yaitu pelaksanaan sosialisasi, pengumpulan data dan survei, pelatihan pembuatan produk, pendampingan teknis monitoring dan pembinaan. Hasil penelitian yaitu memberikan pemberdayaan masyarakat dengan memanfaatkan potensi daerah melalui pengetahuan dan ketrampilan tentang wirausaha dan teknologi tepat guna. Penelitian Ana (2017) menggunakan metode kualitatif dengan tahap pengumpulan data dengan participant observation dan bersifat holistik dan menekankan proses in depth interview, hasil penelitian adalah jumlah tenaga kerja yang terlibat berkurang, waktu pewarnaan berkurang, postur kerja pewarnaan mengalami perbaikan. Menghasilkan katalog online dan jangkauan pemasaran semakin banyak, penjualan meningkat

Tujuan dan manfaat dari penelitian untuk mewujudkan dan meningkatkan keberdayaan UMKM batik tulis Trenggalek dengan konsep ramah lingkungan melalui pelatihan-pelatihan dan penerapan alat produksi yang berteknologi tepat guna yaitu meja gambar motif batik yang merupakan pemberdayaan bagi pengrajin batik tulis yang ramah lingkungan.

\section{METODE}

Desain penelitian melalui penelitian survei adalah populasi yang ada dijadikan sampel dan kuesioner digunakan sebagai alat untuk mengumpulkan data. Data primer penelitian yaitu berasal dari pengrajin batik di Trenggalek melalui wawancara langsung dan melalui kuesioner yang diberikan kepada responden.

Penelitian ini populasinya adalah pemilik sekaligus pengelola usaha batik tulis dan para pengrajin batik dengan kriteria telah mendapatkan pelatihan, pembinaan, pendampingan, dan bantuan teknologi tepat guna yaitu meja gambar replika motif batik di Kabupaten Trenggalek dengan jumlah 32 orang dan dari seluruh jumlah populasi dijadikan sampel sehingga penelitian ini disebut dengan penelitian sensus. 
HASIL

Tabel 1. Koefisien Korelasi

\begin{tabular}{|c|c|c|c|c|c|c|c|}
\hline \multirow{2}{*}{ Model } & \multicolumn{2}{|c|}{ Unstandardized Coefficients } & $\begin{array}{l}\text { Standardized } \\
\text { Coefficients }\end{array}$ & \multirow{2}{*}{$\mathrm{T}$} & \multirow{2}{*}{ Sig. } & \multicolumn{2}{|c|}{ Collinearity Statistics } \\
\hline & B & Std. Error & Beta & & & Tolerance & VIF \\
\hline 1 (Constant) & -29.407 & 9.967 & & -2.950 & .006 & & \\
\hline Pelatihan & .886 & .143 & .726 & 6.218 & .000 & .939 & 1.065 \\
\hline Teknologi_tepat_guna & 390 & .244 & .187 & 1.598 & .121 & 939 & 1.065 \\
\hline
\end{tabular}

Sumber : data primer diolah 2018

Tabel 2. Anova

\begin{tabular}{|c|c|c|c|c|c|c|}
\hline Model & Sum of Squares & Df & Mean Square & $\mathrm{F}$ & $\begin{array}{l}\mathrm{F} \\
\text { Tabel }\end{array}$ & Sig. \\
\hline 1 Regression & 235.865 & 2 & 117.932 & 24.542 & 4.17 & $.000^{\mathrm{a}}$ \\
\hline Residual & 139.354 & 29 & 4.805 & & & \\
\hline Total & 375.219 & 31 & & & & \\
\hline
\end{tabular}

Sumber : data primer diolah 2018.

\section{PEMBAHASAN}

\section{Analisis Regresi Linier Berganda}

Konstanta (a): $-29,407$, nilai konstanta mempunyai nilai negatif artinya apabila skor variabel pelatihan serta variabel teknologi tepat guna tidak ada atau sama dengan nol (0), maka untuk skor keberdayaan akan menjadi semakin berkurang. Yang berarti bahwa tanpa adanya pelatihan dan penggunaan teknologi tepat guna maka pengusaha batik tidak akan berdaya.

Koefisien $b_{1}$ : 0,886 , koefisien variabel pelatihan bernilai positif, artinya pelatihan yang dilakukan berpengaruh signifikan terhadap keberdayaan pengrajin batik yang bersifat positif dan kuat. Jika skor pelatihan semakin meningkat, sehingga keberdayaan pengrajin batik juga akan meningkat semakin tinggi.

Koefisien $b_{2}: 0,390$, koefisien variabel penggunaan teknologi tepat guna bernilai positif, artinya penggunaan teknologi tepat guna berpengaruh tidak signifikan terhadap keberdayaan pengrajin batik. Jika skor nilai penggunaan teknologi tepat guna meningkat, maka keberdayaan pengrajin batik juga akan meningkat

\section{Pengaruh pelatihan dan teknologi tepat guna terhadap keberdayaan pengrajin batik}

Berdasarkan tabel 2 dapat interprestasikan bahwa hasil analisis memperoleh nilai $F_{\text {hitung }}$ sebesar 24,542, sedangkan nilai dari $F_{\text {tabel }}$ sebesar 4,17 sehingga dapat disimpulkan bahwa $F_{\text {hitung }}>F_{\text {tabel, }}$, serta signifikansi $\mathrm{P}<0,05$, maka $\mathrm{H}_{\mathrm{o}}$ ditolak. Artinya pelatihan dan teknologi tepat guna secara bersama-sama berpengaruh terhadap keberdayaan pengrajin batik. Penelitian ini mendukung hasil penelitian Firmansyah (2012) yang mengutarakan bahwa tingkat keberdayaan masyarakat ditentukan oleh dinamika suatu kelompok sasaran serta fasilitator maupun pendamping dari program suatu pemberdayaan. Maka, pendampingan program pemberdayaan yang dilakukan oleh fasilitator (pelatih 
atau instruktur) bagi sekumpulan pengrajin batik yang melaksanakan pelatihan diperlukan untuk meningkatkan kemampuan keahlian dan kemampuan teknologi. Hal ini didukung oleh penelitian Kumalasari (2014) yang menjelaskan pemberdayaan pengrajin batik diperlukan pembinaan dengan mengikuti pelatihan kemampuan teknologi untuk memproduksi batik dan teknologi dalam pemasaran sehingga dapat meningkatkan jumlah produksi dan kualitas produk. Selain itu teknologi tepat guna juga perlu pendampingan agar tercipta keberdayaan bagi pengrajin batik. Hal ini juga didukung oleh penelitian Rahmiyati, Handayani, dan Panjaitan (2015) yang menggunakan teknologi tepat guna untuk pemberdayaan masyarakat miskin dengan adanya pendampingan secara teknis dan non teknis.

Berdasarkan uraian di atas maka disimpulkan bahwa pengrajin batik di Trenggalek yang sudah melakukan pelatihan dari segi produksi, pemasaran, dan sumber daya manusia yang kemudian dilakukan pendampingan dan pembinaan dari instruktur bagi sekelompok pengrajin batik menjadikan keberdayaan semakin meningkat. Selain itu dengan pemberian alat berupa meja gambar ramah lingkungan yang merupakan peralatan teknologi tepat guna yang dipergunakan oleh pengrajin batik di Trenggalek serta dengan melakukan pendampingan secara teknis artinya memberi pengarahan tentang cara menggunakan meja gambar dengan benar serta pendampingan non teknis yaitu pendampingan untuk menghasilkan motif batik pada kain mori dengan memanfaatkan media meja gambar menjadi semakin lebih meningkakan keberdayaan karena adanya program pemberdayaan bagi pengrajin batik yang sudah dilatih, didampingi, dan dibina.

\section{KESIMPULAN}

Pelatihan secara parsial berpengaruh signifikan terhadap keberdayaan pengrajin batik, sedangkan penggunaan teknologi tepat guna secara parsial berpengaruh tidak signifikan terhadap keberdayaan pengrajin batik. Pelatihan dan teknologi tepat guna secara bersama-sama berpengaruh signifikan terhadap keberdayaan pengrajin batik artinya tingkat keberdayaan pengrajin batik ditentukan oleh pelatihan dan penggunaan teknologi tepat guna.

\section{SARAN}

Jika ingin tetap berdaya dan mampu bersaing dalam memproduksi batik, maka pengrajin batik harus aktif mengikuti pelatihan secara formal ataupun non formal sehingga pengrajin batik mampu berinovasi dalam membuat batik. Peningkatan keberdayaan pengrajin batik tidak hanya pada pelatihan dan penerapan teknologi tepat guna, namun juga faktor demografi yaitu jenis kelamin, umur, dan pendidikan dapat menjadi pengembangan teori tentang peningkatan keberdayaan. Peneliti yang ingin mengkaji ulang penelitian serupa disarankan untuk lebih menekankan pada kearifan lokal sebagai faktor pendukung keberdayaan pengrajin batik..

\section{DAFTAR RUJUKAN}

Andarwati, M., dan Jatmika, D. 2017. Analisis Pengaruh Kualitas Sistem Informasi Akuntansi Terhadap Penerimaan Teknologi di Sektor UKM dengan Pendekatan Model TAM. Prosiding Seminar Nasional SIstem Informasi (Senasif). 1(1): 946-956. Malang: Fakultas Teknologi Informasi Universitas Merdeka. 
Chan, CL. 2015. Analisis Pelatihan Manajerial pada PT. Mitra Pinasthika Mulia Surabaya. Jurnal Agora, 3 (1).

Dessler, G. 2006. Manajemen Sumber Daya Manusia, Jilid 2, Edisi ke 7, Alihbahasa: Benyamin Mollan, Prehallindo, Jakarta.

Firmansyah, H. 2012. Tingkat Keberdayaan Masyarakat Dalam Program Pemberdayaan Masyarakat di Kota Banjarmasin dan Kabupaten Tanah Laut. Jurnal Agribisnis Pedesaan. 2(1): 53-67.

Irhandayaningsih, A. 2017. Pengaruh Penggunaan Teknologi Tepat Guna dalam Meningkatkan Produktivitas UKM Batik Tulis di Kampung Batik Kauman Kota Pekalongan. Jurnal Anuva, 1 (1): 11-18.

Iswanaji, Chaidir \& Bondan, S. 2015. Optimalisasi Kampung Batik Ngasem dalam Mengembangkan Industri Batik di Yogyakarta. Prosiding Seminar Nasional dan Call for Paper. FEB Universitas 17 Agusttus 1945 Semarang.

Kumalasari, YY. 2014. Pembinaan dan Pemberdayaan Pengrajin Batik (Studi di Dinas Koperasi, UKM, Perindustrian, Perdagangan, dan ESDM Kabupaten Sidoarjo dan Industri Kecil Kampoeng Batik Jetis Kabupaten Sidoarjo). Jurnal Administrasi Publik, 2(1): 66-70.

Mangkunegara, AP. 2013. Manajemen Sumber Daya Manusia Perusahaan. Remaja Rosdakarya, Bandung.

Muhi, AH. 2009. Teknologi Tepat Guna (TTG) dalam Perspektif Pemberdayaan Masyarakat. Makalah, disampaikan pada Acara Temu Karya Pendampingan Masyarakat Pedesaaan dalam Bidang Pemerintahan, Pembangunan dan Kemasyarakatan di Kabupaten Bekasi (tanggal 13 April 2009 dan 7 Mei 2009).

Rahmiyati, N., Handayani, S., \& Panjaitan, H. 2015. Model Pemberdayaan Masyarakat Melalui Penerapan Teknologi Tepat Guna di Kota Mojokerto. Jurnal Ilmu Ekonomi dan Manajemen, 12(2): 48-62.

Sikula, AF. 1981. Personnel Administration And Human Resources Management.

New York: A. Wiley Trans Edition, By John Wiley \& Sons Inc.

Situmorang, SH., \& Safri, M. 2011. Urgensi Pengembangan Teknologi Tepat Guna untuk UMKM di Kota Medan. Jurnal Ekonom, 14(4).

Saaty, TL. dan Niemira, MP. 2006. A Fremawork for Making a Better Decision How to Make More Effective Site Selection, Store Closing and Other Real Site Selection, Store Closing and Other Real Estate Decisions. Research Review, 13 (1).

Soeprihanto, J. 2001. Penilaian Kinerja dan Pengembangan Karyawan. Jogjakarta: BPFE Fakultas Ekonomi Universitas Gajah Mada

Sukirno, S. 2010. Makro Ekonomi Teori Pengantar. Jakarta: PT. Raja Grafindo Perkasa.

Susilowati, I., Tohir, M., Waridin., Winarni, T., \& Sudaryono, A. 2005. Pengembangan Model Pemberdayaan Masyarakat Pesisir (Usaha Mikro, Kecil, Menengah dan Koperasi UMKMK) dalam Mendukung Ketahanan Pangan di Kabupaten/Kota Pekalongan, Jawa Tengah. Universitas Diponegoro. Jakarta: Riset Unggulan Kemasyarakatan dan Kemitraan (RUKK) Tahun II. 
Sutanto, HA., Sudantoko D., Maktub S. 2012. Strategi Peningkatan Keberdayaan Industri Kecil Konveksi dengan Analysis Hierarchy Process (AHP). Jurnal Jejak, 5(1).

Sutrisno, E. 2009. Manajemen Sumber Daya Manusia. Edisi Pertama, Jakarta: Kencana Prenada Media Group.

Widyasanti, A., Putri SH., \& Dwiratna, SNP. 2016. Upaya Pemberdayaan Masyarakat Melalui Pelatihan Pembuatan Produk Sabun Berbasis Komoditas Lokal di Kecamatan Sukamantri Ciamis. Jurnal Aplikasi Ipteks untuk Masyarakat, 5(1): 29-33. 